\title{
Clinical Profile and Upper Gastrointestinal Endoscopic Findings of Patients Presenting with Liver Cirrhosis with Portal
}

\section{Hypertension}

\author{
*Shatdal Chaudhary ${ }^{1}$, Niraj Kumar Jaiswal ${ }^{1}$, Aakash Shahi ${ }^{2}$, Pradip Chhetri ${ }^{3}$ \\ ${ }^{1}$ Associate Professor, Department of Internal Medicine; ${ }^{2}$ Assistant Professor, Department of Internal Medicine; \\ ${ }^{3}$ Assistant Professor, Department of Community Medicine; Universal College of Medical Sciences, Bhairahawa, Nepal \\ Correspondence:
}

Dr.Shatdal Chaudhary, Ranigaon, Bhairahawa, Nepal.

Email: shatdalchaudhary@yahoo.com,Phone: +977-9817403804

\begin{abstract}
Introduction: Liver cirrhosis is a common problem faced by physicians worldwide and is also responsible for $11^{\text {th }}$ most common cause of death globally. Data regarding prevalence of esophageal varices and other upper gastrointestinal changes in patients with liver cirrhosis is scare in Nepal. So this study was carried out to find clinical profile and upper gastrointestinal endoscopic findings of patients presenting with liver cirrhosis with portal hypertension.

Methods: This was a cross-sectional observational hospital based study conducted in the department of internal medicine and endoscopy unit of the Universal College of Medical Sciences, Bhairahawa, Nepal. The study was done from 21 February 2019 to 20 November 2019 in the patients presented with liver cirrhosis with portal hypertension. Sample size of $80 \pm 10$ was calculated based on the statistics of previous data. The upper gastrointestinal endoscopy was done in all the patients. The data was collected using the predesigned pro-forma.

Results: Total 89 patients with liver cirrhosis were enrolled with mean age of $51.84 \pm 12.26$ years and male: female ratio of 3.68:1. As per Child Pugh classification (CTP) 45 patients (51\%) were in Class C, 33 patients (37\%) were in Class B and 11 patients (12\%) were in Class A. Esophageal varices were present in 51 (57.3\%) patients. According to Westaby classification grade I esophageal varices were seen in 17 (19.1\%), grade II esophageal varices were seen in 26 (29.2\%), grade III esophageal varices were seen in 8 (8.9\%) patients. Portal hypertensive gastropathy (PHG) was seen in 64 (71\%) patients. The association between esophageal varices and PHG grade was found statistically significant $(\mathrm{P}=<0.001)$.

Conclusions: Liver cirrhosis was more commonly seen in middle age males. Esophageal varices and portal hypertensive gastropathy were common endoscopic findings present in patients with liver cirrhosis. There was statistically significant association between esophageal varices and PHG.

Keywords: Cirrhosis of liver, Endoscopy, Esophageal varices, Portal hypertensive gastropathy
\end{abstract}

\begin{tabular}{|l|l|l|}
\hline \multicolumn{2}{|c|}{ Access this article Online } & Article Info. \\
\hline Quick Response Code & Website: & How to cite this article in Vancouver Style? \\
\hline www.jkahs.org.np & $\begin{array}{l}\text { Chaudhary S, Jaiswal NK, Shahi A, Chhetri } \\
\text { P. Clinical Profile and Upper Gastrointestinal } \\
\text { Endoscopic Findings of Patients Presenting with } \\
\text { Liver Cirrhosis with Portal Hypertension. } \\
\text { Karnali Academy of Health Sciences 2020;3(1): }\end{array}$ \\
\cline { 2 - 3 } & $\begin{array}{l}\text { Received: Dec. 15, 2019 } \\
\text { Accepted: Feb. 15, 2020 } \\
\text { Published Online: Feb. 19, 2020 }\end{array}$ \\
& $\begin{array}{l}\text { Conflict of Interest: None, Source of Support: None } \\
\text { The DOI will be functional after the } \\
\text { issue is fully published online as well as } \\
\text { in printed version }\end{array}$ &
\end{tabular}




\section{INTRODUCTION}

Liver cirrhosis is a common problem faced by physicians in clinical practice worldwide. Approximately 0.633 million people in the United States and 7 million people in China are affected with liver cirrhosis. ${ }^{1}$ Worldwide, cirrhosis and it's complications leads to one million deaths per year which makes it $11^{\text {th }}$ most common cause of death globally as of 2019. ${ }^{2}$ In Nepal, deaths due to liver cirrhosis has been increased from 1831 deaths in 1980 to 3175 deaths in $2010 .^{3}$ Cirrhosis with resultant portal hypertension can lead to the formation of collateral vessels within the mucosa and submucosa of the distal oesophagus, the gastroesophageal junction or the gastric fundus which may rupture and cause life threatening upper gastrointestinal bleeding. ${ }^{4,5}$ It still has a 15-20\% mortality at 6 weeks in spite of recent progress in it's management. ${ }^{6}$ In Patients with compensated liver cirrhosis without oesophageal varices, varices may develop at a rate of $7-8 \%$ per year. ${ }^{7}$ Upper gastrointestinal bleeding from ruptured varices can be life threatening and occurs mostly when the portal pressure becomes $\geq 12 \mathrm{~mm} \mathrm{Hg}$ and. ${ }^{8}$ The American Association for the Study of Liver Diseases and the Baveno IV Consensus Conference on portal hypertension recommended that all patients with cirrhosis should undergo endoscopy to assess presence and size of varices at the time of liver cirrhosis diagnosis.
This procedure should be repeated at 2-3 years in compensated cirrhosis and annually in decompensated cirrhosis if no varices are present at index endoscopy. ${ }^{9,10}$ Data regarding prevalence of esophageal varices and other upper gastrointestinal changed in patients with liver cirrhosis is scare in Nepal. So this study was done to find out clinical profile and upper gastrointestinal endoscopy findings of patients presenting with liver cirrhosis with portal hypertension.

\section{MATERIALS AND METHODS}

This was a cross-sectional observational hospital based study conducted in the department of internal medicine and endoscopy unit of the Universal College of Medical Sciences -Teaching Hospital (UCMS-TH), Bhairahawa, Nepal. The study was carried out from 21 February 2019 to 20 November 2019. This study was approved by the ethical review committee of the institute. Written informed consent was taken from all the patients.

All the patients aged $>16$ years presented with liver cirrhosis with portal hypertension in the internal medicine department of UCMS-TH during the study period were included in the study. Sample size of $80 \pm 10$ was calculated based on the statistics of previous data of prevalence of esophageal varices in $40 \%$ patients. Patients who did not give written consent for the study or aged $\leq 16$ years were 
excluded. Patients who were unfit for endoscopy or hemodynamically unstable (like history of recent myocardial infarction, arrhythmia, unconscious, uncooperative, restless or in shock) were also excluded.

Liver cirrhosis with portal hypertension was diagnosed based on the ground of clinical examination, and abdominal ultrasound with color doppler study. Abdominal ultrasound and doppler study was done to look for presence of coarse heterogenous echotexture, surface nodularity, segmental hypertrophy or atrophy, caudate width: right lobe width $>0.65$, splenomegaly, portal vein diameter $>13$ $\mathrm{mm}$, slow portal venous flow $<15 \mathrm{~cm} / \mathrm{sec}$, hepatic arteries: corkscrew appearance, portal systemic collateral, extrahepatic or portal vein obstruction, and presence of ascites.

After enrolment in the study, data was collected as per predesigned proforma. Detailed history, general and systemic examination was performed with special emphasis for looking for features of cirrhosis and portal hypertension. Laboratory tests such as hemoglobin $(\mathrm{Hb})$, blood group, total leucocyte count (TLC), differential leucocyte count (DLC), platelet, prothrombin time (PT), international normalized ratio (INR), liver function test (LFT), renal function test (RFT), sodium $(\mathrm{Na})$, potassium $(\mathrm{K})$, random blood glucose (RBS), hepatitis B surface antigen, anti hepatitis C antibodies, human immune deficiency virus I and II were done. Ultrasonography of abdomen and pelvis with color doppler with particular emphasis on portal vein diameter, portal systemic collaterals, extrahepatic or portal vein obstruction, hepatic echogenicity, splenomegaly, presence of ascites was done.

The upper gastrointestinal endoscopy was done in all the patients on the same day of presentation if they present during working hours or the next immediate working day. But patients who were hemodynamically unstable, endoscopy was done after resuscitation and stabilization of the patients. Fujinon videoendoscope model no. EG-250WR5 was used for the endoscopy. Patient was kept fasting for 6 hours before the procedure. The endoscopy was performed in the endoscopy room under $10 \%$ lignocaine sprays by an experienced endoscopist. Endoscopy was performed in left lateral position. Esophagus, stomach and upper duodenum were visualized for mucosal changes and presence of varices especially by taking the tip of the instrument close to the mucosa. Esophageal varices were classified according to Westaby classification: ${ }^{11}$

Grade I: Varices extending just above the mucosal level, which can be depressed with insufflations. 
Grade II: Varices projecting by one-third of the luminal diameter that cannot be compressed with air insufflation.

Grade III: Varices projecting up to $50 \%$ of the luminal diameter and in contact with each other. Gastric varices were classified as per Sarin's classification. ${ }^{12}$

\section{Gastro-oesophageal varices Type 1}

(GOV1): Continuation of oesophageal varices into the lesser curvature.

2. Gastro-oesophageal varices Type 2 (GOV2): Oesophageal and fundal varices are present in continuity with the greater curvature.

3. Isolated gastric varices Type 1 (IGV1): Fundal varices are present in the cardia in the absence of oesophageal varices.

4. Isolated gastric varices Type 2 (IGV2):

Fundal varices present in the stomach outside of cardio-fundal region or first part of duodenum.

The fundus was carefully looked to detect the portal hypertensive gastropathy (PHG) and graded as per the McCormack classification: ${ }^{13}$

1. Mild PHG: Fine pink speckling (scarlatina type rash), superficial reddening, especially on rugal surface (striped appearance), fine white reticular pattern separating areas of raised edematous mucosa (snake skin)

2. Severe PHG: Discrete red spots (analogous to cherry red spots in esophagus), diffuse hemorrhagic gastritis
The data obtained using the pro-forma was entered in the computer in windows office, excel spread sheet and transferred to SPSS version 20. Statistical analysis was done using SPSS for window software. Categorical data were expressed as frequencies and corresponding percentage. The mean difference between different blood parameters with PHG category is calculated by independent sample t- test. The association between PHG grade and esophageal varices was calculated by using Chi-Square test. Level of significance for all analytical tests were set at 0.05 and $\mathrm{P}$ value $<0.05$ was considered to be statistically significant.

\section{RESULTS}

Total 89 patients with liver cirrhosis were enrolled in this study and analysed statistically. Baseline characteristics of the study subjects are depicted in table 1.

Table 1: Baseline characteristics of the patients

\begin{tabular}{ll}
\hline Parameters & Mean \pm SD \\
\hline Age (years) & $51.84 \pm 12.6$ \\
Pulse (Beats/min) & $89.35 \pm 12.36$ \\
SBP (mmHg) & $113.15 \pm 17.52$ \\
DBP (mmHg) & $72.25 \pm 11.29$ \\
BMI (Kg/M ${ }^{2}$ ) & $22.43 \pm 2.52$ \\
Haemoglobin (g/dl) & $9.46 \pm 2.39$ \\
TLC (/cu.mm) & $9630 \pm 4199.61$ \\
Platelets (/Cu.mm) & $100539.32 \pm 34862.50$ \\
Na (meq/dl) & $137.23 \pm 3.06$ \\
K (meq/dl) & $3.89 \pm 0.55$ \\
INR & $1.54 \pm 0.47$ \\
Serum Urea (mg/dl) & $40.04 \pm 15.59$ \\
Serum Creatinine (mg/dl) & $1.09 \pm 0.22$ \\
Total Protein (mg/dl) & $6.52 \pm 0.69$ \\
Albumin ( mg/dl) & $3.38 \pm 0.49$ \\
Total Bilirubin (mg/dl) & $4.84 \pm 4.56$
\end{tabular}




\begin{tabular}{ll}
\hline AST (IU/L) & $154.71 \pm 93.06$ \\
ALT (IU/L) & $70.12 \pm 44.28$ \\
$\begin{array}{l}\text { Alkaline phosphatise } \\
\text { (IU/L) }\end{array}$ & $265.13 \pm 138.67$ \\
$\begin{array}{l}\text { Duration of hospital Stay } \\
\text { (days) }\end{array}$ & $6.35 \pm 2.40$ \\
\hline
\end{tabular}

Mean age of patients in the present study was $51.84 \pm 12.26$ years (Range: 31yrs to 89 years). Most of our patients were adults in their fifth and sixth decade of life and together they constituted $57 \% \quad(n=51)$ of total study population (Figure 1). Highest number of patients ( $\mathrm{n}=26,29.21 \%)$ belong to $51-60$ age group followed by 41-50 age group $(n=25$, 28.09\%), 31-40 age group $(n=19,21.35 \%)$, 61-70 age group $(n=11,12.36 \%)$ and $>70$ age group ( $n=8,8.99 \%)$ There were more males $(n=70,78.65 \%)$ then females $(n=19,21.35 \%)$ in the present study with male:female ratio of3.68:1.

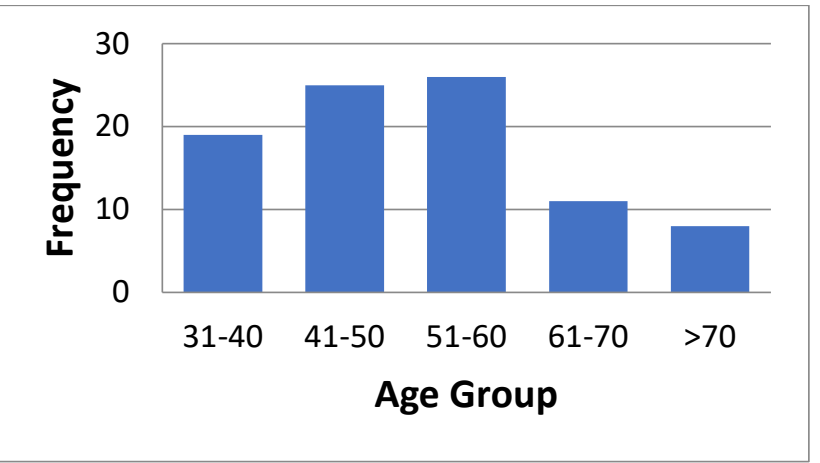

Figure 1: Age distribution of the patients

Patients included in the present study were from 11 nearby districts from the study site. Most number of patients were from Rupandehi ( $n=40,44.94 \%)$ followed by Kapilvastu $(n=14$, $15.73 \%)$, Nawalparasi west $(n=10,11.24 \%)$,
Dang(n=7, 7.87\%), Palpa ( $\mathrm{n}=5, \quad 5.62 \%)$, Pyuthan ( $n=4,4.49 \%)$, Gulmi ( $n=3,3.37 \%)$, Arghakhachi ( $\mathrm{n}=2,2.25 \%)$, Rolpa $(\mathrm{n}=2$, 2.25\%), Kaski ( $\mathrm{n}=1,1.12 \%)$ and Parbat $(\mathrm{n}=1$, $1.12 \%)$ districts of Nepal respectively. Ethnically, majority of the patients $49.44 \%$ $(\mathrm{n}=44)$ were janjatis, followed by dalits $13.48 \% \quad(n=12)$, chettris $13.48 \% \quad(n=12)$, brahmins $12.36 \%(\mathrm{n}=11)$, madhesis $10.11 \%$ $(\mathrm{n}=9)$, and muslims $1.12 \%(\mathrm{n}=1)$ respectively. Majority of patients $25.84 \% \quad(n=23)$ were farmers by occupation, followed by shopkeepers 21.35\% ( $n=19)$, driver 14.61\% $(\mathrm{n}=13)$, businessmen $\quad 10.11 \% \quad(\mathrm{n}=9)$, housewives $10.11 \%(n=9)$, retired army men 8.99\% ( $\mathrm{n}=8)$ servicemen $7.87 \%(\mathrm{n}=7)$, and labourers $1.12 \%(\mathrm{n}=1)$.

The most common cause of cirrhosis was ethanol ingestion which was found in 83 (93.26\%) patients. Chronic hepatitis B infection was the second most common cause which was seen in 3 (3.37\%) patients followed by chronic hepatitis C infection in 1 (1.12\%) patients. The cause of cirrhosis was unknown in 2 (2.24\%) patients. Clinical and laboratory characteristics are given in table 1 .

Each patient had one or more presenting complains at admission. The commonest presenting complain was disorientation in 35 patients (39.3\%), UGIB in 31 (34.8\%), abdominal distension in 28 (31.5\%), altered sleep in 26 (29.2\%) fever in 15 (16.9\%), 
drowsiness in $10(11.2 \%)$ and coma in 8 (8.99\%) patients. The commonest clinical sign at presentation was ascites which was present in 79 patients (88.7\%), icterus in 63 (70.8\%), splenomegaly in 53 (59.6\%), pallor in 48 (53.9\%), edema in 41 (46.1\%), petechiae in 31 (34.8\%), asterixis in 21 (23.6\%), gynaecomastia in 19 (21.3\%) and palmar erythema in 19 (21.3\%) patients (table 2).

Table 2: Clinical features of the patients

\begin{tabular}{ll}
\hline Clinical Presentation & Frequency N (\%) \\
\hline Disorientation & $35(39.3 \%)$ \\
UGIB & $31(34.8 \%)$ \\
Abdominal distension & $28(31.5 \%)$ \\
Altered sleep & $26(29.2 \%)$ \\
Fever & $15(16.9 \%)$ \\
Drowsiness & $10(11.2 \%)$ \\
Coma & $8(8.99 \%)$ \\
Signs & \\
Ascites & $79(88.7 \%)$ \\
Icterus & $63(70.8 \%)$ \\
Splenomegaly & $53(59.6 \%)$, \\
Pallor & $48(53.9 \%)$ \\
Edema & $41(46.1 \%)$ \\
Petechiae & $31(34.8 \%)$ \\
Asterixis & $21(23.6 \%)$ \\
gynaecomastia & $19(21.3 \%)$ \\
\hline
\end{tabular}

Palmar erythema $19(21.3 \%)$

The patients were grouped according to Child Pugh score (CTP), in which 45 patients (51\%) were in Class C, 33 patients (37\%) were in Class B and remaining 11 patients (12\%) were in Class A (Figure 2). Majority of our patients were in class $\mathrm{C}$ which shows that they were in advance stage of liver disease (Figure 2).

\section{Child Pugh Classification}

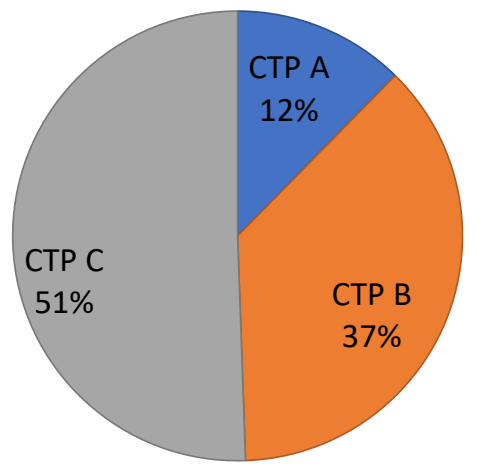

Figure 2: Distribution of patients according to Child Pugh Score

Upper gastrointestional (UGI) endoscopy was done in all the patients and looked for varices, portal hypertensive gastropathy or any other endoscopic findings. UGI Endoscopy findings were normal in 24 (27\%) patients. Esophageal Varies were present in 51 (57.3\%) patients. 


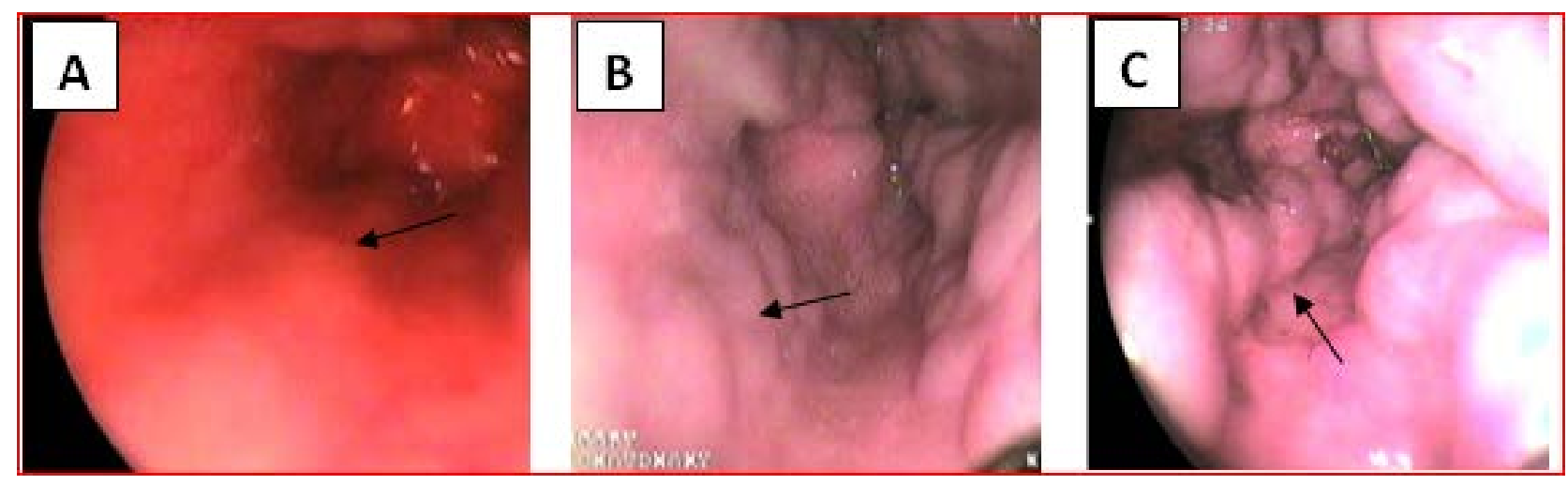

Figure 3: Esophageal varices as per Westaby classification- A Grade I, B Grade II and C Grade III

Esophageal varices were classified according to Westaby classification. Grade I esophageal varices were seen in 17 (19.1\%) patients, grade II esophageal varices were seen in 26 (29.2\%), grade III esophageal varices were in 8 (8.9\%) patients (Figure 3 and 4). Among 51 patients with esophageal varices, one column of varix was present in 9 (17.65\%) patients, two columns of varices were present in 15 (29.41\%) patients and 3 columns of varies were present 20 (39.22\%) patients and four columns were present in 7 (13.73\%) patients.

PHG was seen in 64 (71\%) patients. PHG was mild in 54 (84.38\%) patients and severe in 10 (15.62\%) patients. (Figure 5)

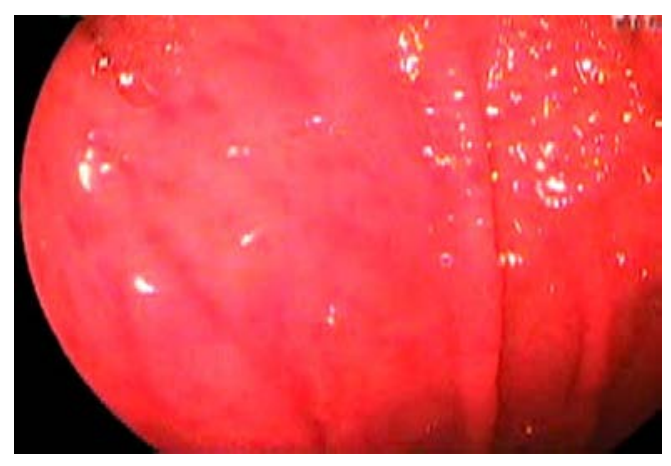

Figure 5: Mild portal hypertensive gastropathy.

There were 5 (5.62\%) patients of gastric varices. As per Sarin's classification there were 3 (3.37\%) patients of gastro-osophageal varices of type II (GOV II). There were 1 (1.12\%) patient each for gastro-oesophageal varices of type I (GOV I) and isolated gastric varix of type I (IGV I). Other findings seen during endoscopy were nonerosive antral gastritis 7 (7.87 \%), erosive gastritis 3 (3.37\%), hiatus hernia 2 (2.25\%), erosive duodenitis 2 (2.25\%), duodenal ulcer 1 (1.12\%) esophageal ulcer 1 (1.12\%) and distal esophagitis 1 (1.12\%) patient (Figure4).

The mean difference between different blood parameters with PHG category is calculated by 
independent sample t- test. It was seen that the mean difference of haemoglobin, blood urea, serum creatinine, ALP, prothrombin time and
INR with PHG category was found to be statistically significant (table 3)

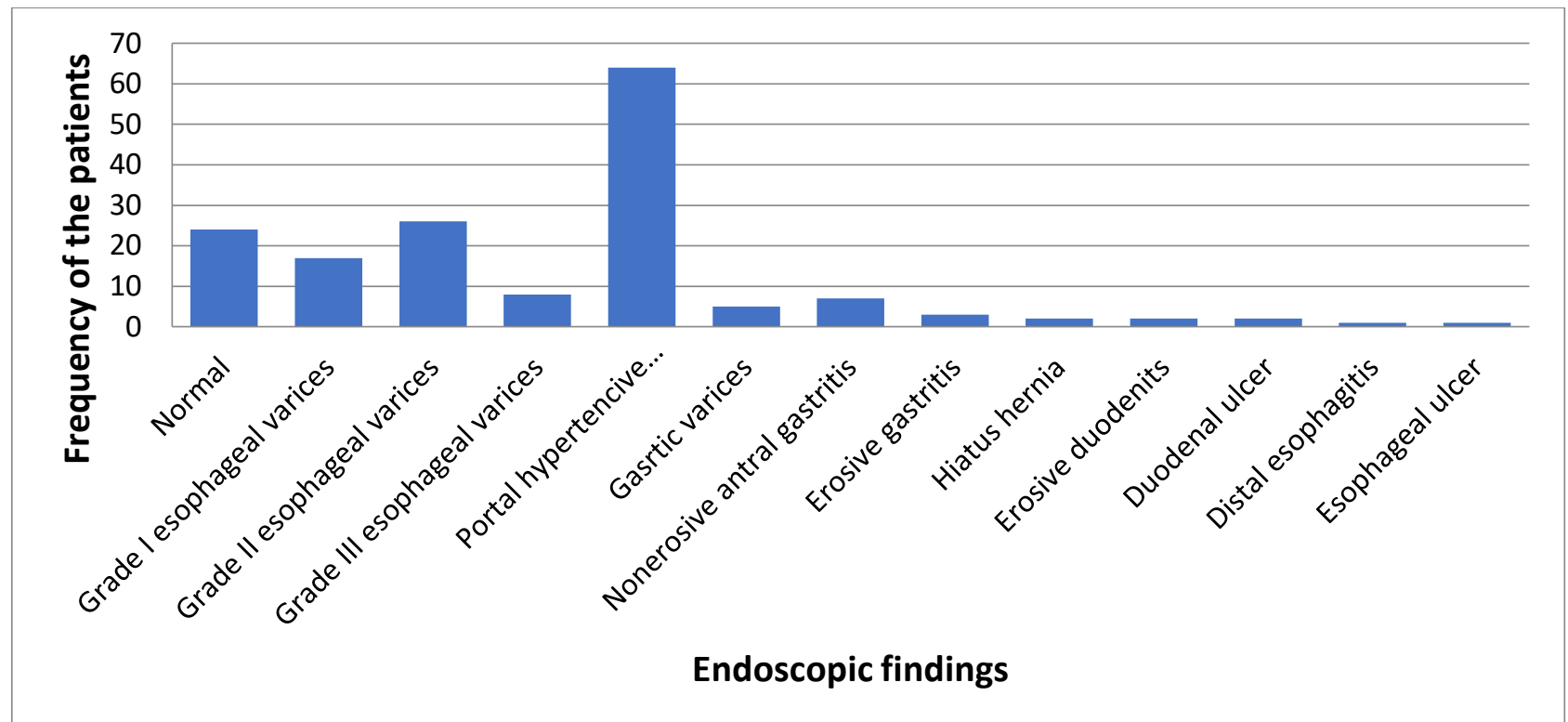

Figure 4: Upper gastrointestinal endoscopy findings.

Table 3: Correlation between various blood parameters and PHG

\begin{tabular}{|c|c|c|c|c|c|c|}
\hline \multicolumn{2}{|c|}{$\begin{array}{l}\text { Biochemical } \\
\text { Parameter }\end{array}$} & \multirow{2}{*}{$\begin{array}{r}\text { Number(N) } \\
25\end{array}$} & \multirow{3}{*}{$\begin{array}{c}\text { Mean } \\
10.580\end{array}$} & \multirow{3}{*}{$\begin{array}{r}\begin{array}{c}\text { Standard } \\
\text { Deviation }\end{array} \\
2.3101\end{array}$} & \multirow{2}{*}{$\begin{array}{l}\text { Mean } \\
\text { difference }\end{array}$} & \multirow{2}{*}{$\begin{array}{c}\text { P-value } \\
.005\end{array}$} \\
\hline Hb & No & & & & & \\
\hline & PHG & & & & & \\
\hline & PHG & 64 & 9.023 & 2.3185 & & \\
\hline \multirow[t]{3}{*}{ TLC } & No & 25 & 9040.00 & 3508.442 & -820.938 & .402 \\
\hline & PHG & & & & & \\
\hline & PHG & 64 & 9860.94 & 4343.673 & & \\
\hline \multirow[t]{4}{*}{ Platelet } & No & 25 & 1.026400 & .2992474 & .0292125 & .726 \\
\hline & PHG & & & & & \\
\hline & PHG & 64 & .997188 & .3705957 & & \\
\hline & PHG & 64 & 3.970 & .5784 & & \\
\hline \multirow[t]{3}{*}{ Urea } & No & 25 & 32.520 & 15.6475 & -10.4581 & .004 \\
\hline & PHG & & & & & \\
\hline & PHG & 64 & 42.978 & 14.7951 & & \\
\hline \multirow{3}{*}{$\begin{array}{l}\text { Creatinin } \\
\text { e }\end{array}$} & No & 25 & .996 & .1369 & -.1259 & .016 \\
\hline & PHG & & & & & \\
\hline & PHG & 64 & 1.122 & .2420 & & \\
\hline \multirow{3}{*}{$\begin{array}{l}\text { Total } \\
\text { bilirubin }\end{array}$} & No & 25 & 5.012 & 4.6049 & .2323 & .831 \\
\hline & PHG & & & & & \\
\hline & PHG & 64 & 4.780 & 4.6074 & & \\
\hline \multirow[t]{3}{*}{ AST } & No & 25 & 150.790000 & 77.589 & -5.443 & .807 \\
\hline & PHG & & & & & \\
\hline & PHG & 64 & 156.230000 & 99.662 & & \\
\hline
\end{tabular}




\begin{tabular}{|c|c|c|c|c|c|c|}
\hline ALT & $\begin{array}{l}\text { No } \\
\text { PHG } \\
\text { PHG }\end{array}$ & 25 & 70.68 & $\begin{array}{l}45.084 \\
44.667\end{array}$ & .774 & .942 \\
\hline ALP & $\begin{array}{l}\text { No } \\
\text { PHG } \\
\text { PHG }\end{array}$ & 25 & $\begin{array}{l}222.56 \\
281.77\end{array}$ & $\begin{array}{r}83.426 \\
153.342\end{array}$ & -59.206 & .022 \\
\hline $\begin{array}{l}\text { Total } \\
\text { protein }\end{array}$ & $\begin{array}{l}\text { No } \\
\text { PHG } \\
\text { PHG }\end{array}$ & 25 & $\begin{array}{l}6.656 \\
6.457\end{array}$ & $\begin{array}{l}.5635 \\
.7468\end{array}$ & .1989 & .233 \\
\hline $\begin{array}{l}\text { S. } \\
\text { albumin }\end{array}$ & $\begin{array}{l}\text { No } \\
\text { PHG } \\
\text { PHG }\end{array}$ & 25 & $\begin{array}{l}3.452 \\
3.350\end{array}$ & $\begin{array}{l}.4602 \\
.5033\end{array}$ & 1020 & .382 \\
\hline PT & $\begin{array}{l}\text { No } \\
\text { PHG } \\
\text { PHG }\end{array}$ & 64 & $\begin{array}{l}20.124 \\
23.088\end{array}$ & $\begin{array}{l}3.5406 \\
7.3317\end{array}$ & -2.9635 & .012 \\
\hline INR & $\begin{array}{l}\text { No } \\
\text { PHG } \\
\text { PHG }\end{array}$ & 25 & 1.364000 & $\begin{array}{l}.2195260 \\
.5278655\end{array}$ & -.2386563 & .032 \\
\hline
\end{tabular}

The association between PHG grade and esophageal varices was calculated by using Chi-Square test and it was found statistically significant $(\mathrm{P}=<0.001)$ (table 4$)$.

Table 4: Association between esophageal varices with PHG

\begin{tabular}{llrrrrr}
\hline \multicolumn{2}{l}{$\begin{array}{l}\text { Association between esophageal } \\
\text { varices with PHG }\end{array}$} & \multicolumn{2}{c}{ PHG Grade } & \multicolumn{2}{c}{$\begin{array}{c}\text { Chi- } \\
\text { Square }\end{array}$} & P-Value \\
\hline $\begin{array}{l}\text { Esophageal } \\
\text { Varices }\end{array}$ & Yes & Count & 0 & 51 & 51 & \\
& $\%$ & $0.0 \%$ & $100.0 \%$ & $100.0 \%$ & \\
& No & Count & 25 & 13 & 38 & \\
& $\%$ & $65.8 \%$ & $34.2 \%$ & $100.0 \%$ & \\
Total & Count & 25 & 64 & 89 & & \\
& $\%$ & $28.1 \%$ & $71.9 \%$ & $100.0 \%$ & 45.65 & $<0.001$ \\
\hline
\end{tabular}

\section{DISCUSSION}

This was a hospital based, cross-sectional study where 89 patients with liver cirrhosis were evaluated for clinical profile and endoscopic findings. Our study provides comprehensive data on the epidemiology and clinical and endoscopic findings of liver cirrhosis. Mean age of patients in this study was $51.84 \pm 12.26$ years with male : female ratio 
of 3.68 : 1. Similar study was done in Karachi in 150 patients and had a mean age of $52.45 \pm$ 12.27 years. ${ }^{14}$ Another study was carried out by Maskey $\mathrm{R}$ et al. in Dharan in 105 patients where the mean age was $49.06 \pm 11.27$ years. This can be explained as it takes many years of ethanol drinking to develop liver cirrhosis. ${ }^{15} \mathrm{In}$ our study males outnumbered the females. This is similar to results seen in other studies where males were involved in $72.5 \%$ and $80.7 \%$ respectively. ${ }^{16-17}$ The trend of alcohol intake is more in men as compared to women, as men have easy access and are lesser judged on a social basis regarding their alcohol consumption. Furthermore, male dominance in our society might have led to males getting more access to hospitalization and treatment as compared to females. Ethnically, cirrhosis was seen more commonly in janjatis (49.44\%) and dalits (13.48\%) and least commonly in muslims. Result were found similar to other studies where mongols were involved in $49.44 \%$ patients. $^{16}$ In another study from Assam where only $7.7 \%$ patients were muslims. ${ }^{18}$ It can be explained as alcohol consumption is culturally more accepted in janjatis and religiously unacceptable in the muslims.

The three most common presentations were disorientation in $39.3 \%$ patients, upper gastrointestinal bleeding 34.8\%, abdominal distension in $31.5 \%$. In study done by Bhattacharyya et al. in Assam the most common symptoms at presentation were leg swelling (80.5\%), abdominal swelling (74.3\%), Gastro intestinal bleed (43.4\%), jaundice (36.3\%), low urine output (31\%) and altered sensorium (23\%). ${ }^{18}$ These findings can be explained with the fact that being a hospital based study, most of patients present with one of the complication or decompensation of liver cirrhosis.

The commonest clinical finding at presentation was ascites which was present in $88.7 \%$ patients, icterus in $70.8 \%$, splenomegaly in $59.6 \%$, pallor in $53.9 \%$, edema in $46.1 \%$, petechiae in $34.8 \%$, asterixis in $23.6 \%$, gynaecomastia in $21.3 \%$ and palmar erythema in $21.3 \%$ patients. In another study done by Suthar et al. in Ahmedabad, icterus and ascites were commonest findings on examination which were seen in $60 \%$ patients. Other findings were anaemia (30\%), dilated veins over abdomen (16\%), pedal edema (16\%), and spider naevi (4\%). ${ }^{19}$

As per CTP classification, 51\% patients were in Class C, 37\%patients were in Class B and $12 \%$ patients were in Class A. Results are similar to another study done in Kathmandu by Tiwari et al. where $12.4 \%$ patients were in CTP class A, $35.1 \%$ in CTP class B and $52.5 \%$ patients were in CTP class C. ${ }^{20}$ This shows that most of our patients have presented late in advance stage of cirrhosis. This may be because of poverty or low level of awareness 
among the patients which is commonly seen in under developed countries like ours. Whereas study from Singapore done by Chang PE et al. has more patients in CTP class A (76.8\%) followed by CTP class B (18.3\%) and least in CTP class C (5\%). ${ }^{21}$ In this study esophageal varies were present in 57.3\% patients. Among these Westaby classification grade I esophageal varices were seen in 19.1\% patients, grade II esophageal varices were seen in $29.2 \%$ patients and grade III esophageal varices were in $8.9 \%$ patients.

In another study conducted in Chitwan, gastrooesophageal varices observed in 57.5\% patients. ${ }^{16}$ In another study from Pokhara, grade I, grade II and grade III varices were present in $33 \%, 17 \%$ and $8 \%$ of the patients, respectively, whereas $42 \%$ of the patients had no varices. ${ }^{17}$ In the study done by Suthar et al. in 50 patients $60 \%$ patients showed varices, among them 9 patients had grade I varices, while 11 and 10 patients had grade II and grade III varices respectively. ${ }^{19}$ In a study done in Tanzania among 223 newly diagnosed cirrhotics, esophageal varices were found in $39.5 \%$ patients. $^{22}$ In the study done in Kathmandu, esophageal varices were present in $89.6 \%$ patients among these according to McCormack classification 36.5\% had small $\mathrm{EV}$, and $63.5 \%$ had large $\mathrm{EV} .{ }^{20} \mathrm{In}$ this study PHG were seen in 64 (71\%) patients whereas PHG was present in $67.1 \%$ patients in the study done by Tiwari et al. ${ }^{20}$

\section{CONCLUSIONS}

Liver cirrhosis was more commonly seen in middle age males. The most common presenting complains were disorientation, upper gastrointestinal bleeding and abdominal distension. The common clinical findings at presentation were ascites, icterus and splenomegaly. Esophageal varices and portal hypertensive gastropathy were common endoscopic findings present in patients with liver cirrhosis. There was statistically significant difference between mean of haemoglobin, blood urea, serum creatinine, alkaline phoshatase and prothrombin time with different categories of portal hypertensive gastropathy. The association between esophageal varices and portal hypertensive gastropathy was also found to be statistically significant.

Acknowledgement: Authors are indebted to all our patients and staff of endoscopy unit of UCMS-TH.

\section{REFERENCES}

1. Xiao J, Wang F, Wong NK, He J, Zhang R, Sun R, et al. Global liver disease burdens and research trends: Analysis from a Chinese perspective. J Hepatol. 2019;71(1):212-21.

CrossRef | Google Scholar | PubMed

2. Asrani SK, Devarbhavi H, Eaton J, Kamath PS. Burden of liver diseases in the world. Journal of Hepatology. 2019 Jan;70(1):151-171. CrossRef | Google Scholar | PubMed

3. Mokdad ADL, Shahraz S, Lozano R, Mokdad AH, Stanaway J, Murray CJ, et al. Liver cirrhosis mortality in 187 countries between 1980 and 2010: a systematic analysis. BMC Med. 2014;12(145):124.

CrossRef | Google Scholar | PubMed

4. Kitano S, Terblanche J, Kahn D, Bornman PC: Venous anatomy of the lower oesophagus in portal hypertension: practical implications. Br J Surg 1986; 73: 525-531.

CrossRef $\mid$ Google Scholar $\mid \underline{\text { PubMed }}$ 
5. Spence RA, Sloan JM, Johnston GW, Greenfield A: Oesophageal mucosal changes in patients with varices. Gut 1983; 24: 1024-1029.

CrossRef | Google Scholar | PubMed

6. Carbonell N, Pauwels A, Serfaty L et al. Improved survival after variceal bleeding in patients with cirrhosis over the past two decades. Hepatology 2004;40:652-9.

CrossRef $\mid$ Google Scholar | PubMed

7. D’Amico G, Morabito A, D’Amico M, Pasta L, Malizia G, Rebora P, et al: Clinical states of cirrhosis and competing risks. J Hepatol 2018; 68: 563-576.

CrossRef | Google Scholar | $\underline{\text { PubMed }}$

8. Vorobioff JD, Groszmann RJ: Hepatic venous pressure gradient measurement in pre-primary and primary prophylaxis of variceal hemorrhage. Ann Hepatol 2013; 12: 22-29.

CrossRef | Google Scholar | Full Text

9. Silva G. New serum markers for predicting oesophageal varices: is it a reality? J Gastroenterol Hepatol 2013; 28:112-121.

CrossRef | Google Scholar | PubMed

10. Franchis RD. Expanding consensus in portal hypertension Report of the Baveno VI Consensus Workshop: Stratifying risk and individualizing care for portal hypertension. Journal of Hepatology. 2015;63:743-752.

CrossRef | Google Scholar | PubMed

11. Westaby D, Macdougall BR, Melia W, Theodossi A, Williams R. A prospective randomized study of two sclerotherapy techniques for esophageal varices. Hepatology. 1983; 3(5):681-4.

CrossRef | Google Scholar | PubMed

12. Sarin SK, Lahoti D, Saxena SP, Murthy NS, Makwana UK. Prevalence, classification and natural history of gastric varices: a long-term follow-up study in 568 portal hypertension patients. Hepatology. 1992; 16(6):1343-9.

CrossRef | Google Scholar | PubMed

13. McCormack TT, Sims J, Eyre-Brook I, Kennedy H, Goepel J, Johnson AG, Triger DR: Gastric lesions in portal hypertension: inflammatory gastritis or congestive gastropathy?. Gut. 1985, 26(11):122632.

$\underline{\text { CrossRef | Google Scholar | PubMed }}$

14. Qazi Arisar FA, Khan SB, Umar A. Hepatic encephalopathy in chronic liver disease; predisposing factors in a developing country. Asian J Med Sci. 2014 Sep 16;6(2):35-42.

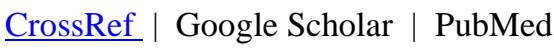

15. Maskey R, Karki P, Ahmed SV, Manandhar DN. Clinical profile of patients with cirrhosis of liver in a tertiary care hospital, Dharan, Nepal.Nepal Med Coll J. 2011 Jun;13(2):115-8.

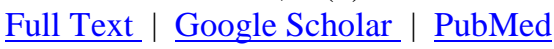

16. Bhattarai S, Gyawali M, Dewan KR, Shrestha G. Demographic and Clinical Profile in Patients with Liver Cirrhosis in a Tertiary Care Hospital in Central Nepal.J Nepal Med Assoc. 2017;56(208):401-6.

CrossRef | Google Scholar | Full Text

17. Pathak O K, Paudel R, Panta OB, Pant HP, Giri BR, Adhikari B. Retrospective study of the clinical profile and prognostic indicators in patients of alcoholic liver disease admitted to a tertiary care teaching hospital in Western Nepal. Saudi Journal of Gastroenterology. 2009;15(3): 171-175.

CrossRef | Google Scholar | PubMed

18. Bhattacharyya M, Barman NN, Goswami B. Clinical profile of cirrhosis of liver in a tertiary care hospital of Assam, North East India. IOSR Journal of Dental and Medical Sciences. 2016 Jan; 15(1):21-27.

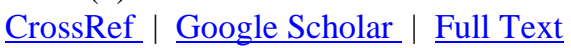

19. Suthar H, Suthar K, Mewada B. Clinical profile of cases of alcoholic liver disease. Int J Med Sci Public Health. 2013; 2(2): 394-398.

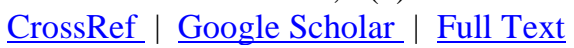

20. Tiwari P S, Kc S, Sharma D, Paudel MS, Mandal A. Prevalence of Portal Hypertensive Gastropathy in Chronic Liver Disease and Correlation with the Severity of Liver disease. Cureus. 2019;11(8): e5454.

$\underline{\text { CrossRef }|~ G o o g l e ~ S c h o l a r ~| ~ P M C ~}$

21. Chang PE, Wong GW, Li JW, Lui HF, Chow WC, Tan CK. Epidemiology and Clinical Evolution of Liver Cirrhosis in Singapore. Ann Acad Med Singapore. 2015;44:218-225.

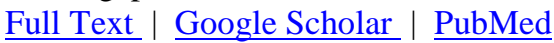

22. Gunda DW, Kilonzo SB, Mamballah Z, et al. The magnitude and correlates of esophageal Varices among newly diagnosed cirrhotic patients undergoing screening fibre optic endoscope before incident bleeding in North-Western Tanzania; a cross-sectional study. BMC Gastroenterol. 2019;19(1):203.

CrossRef $\mid \underline{\text { Google Scholar } \mid \text { PubMed }}$ 